\title{
Effects of Transformer Connection on Voltage Sag Characterization
}

\author{
Parijat Deb ${ }^{1}$, Amit Gupta ${ }^{2}$ \\ ${ }^{1}$ PG Scholar, Gyan Ganga College of Technology, Jabalpur, M.P (India) \\ ${ }^{2}$ Asst.Professor, Gyan Ganga College of Technology, Jabalpur, M.P (India)
}

\begin{abstract}
Day by day with the increase in demand of power supply, people are also becoming aware of power quality. Present generation wants advanced power plant design with the increment of power supply and also the power supply must be of good quality. So, to design power plant, power engineers need to concentrate on how the quality of supply can be improved along with fulfilling all the demands at the same time. In today's era, people are using so many electronic or sensitive devices as per comfort and the same will be happen in future also. These devices are one of the major causes of power quality disturbance. To maintain the quality of the power, engineers need to design their system in a way such that these devices can not seriously affect the quality of the power. In this paper disturbance of power quality due to system voltage profile disturbance is discussed. In this, voltage sag is taken as serious concern for hampered power quality. Voltage sag occurs due to fault in the system and transformer connections play an important role in this. For the analysis, software used is MATLAB/SIMULINK.
\end{abstract}

Keywords: Power Quality, Voltage sag, MATLAB/SIMULINK, Non-Rectangular Sag, Transformer Connection.

\section{Introduction}

With the advancement in the life style of people, power supply demand is increasing. People as per their comfort are using so many devices which are quite sensitive to the voltage profile of the power supplied to them. These sensitive non-linear devices, fault conditions and also lightening strikes are the main causes for giving rise to voltage sag in the pure sinusoidal waveform.

Voltage sag distorts the voltage waveform which in turn becomes the main reason of poor quality of power in the system. Voltage sag due to fault such as single line to ground, line to line, double line to ground and 3 phase fault on different transformer connections such as stardelta, delta-delta, delta-star, star-star are being discussed in this paper. Voltage sag is basically defined as decrease in RMS value of voltage for short duration say 0.5 to 30 cycles.[1][2] Voltage sag is characterized on the basis of magnitude, duration, phase angle jump and unbalance of sag.[6]

\section{Voltage Sag in Brief}

\section{A. Characterization}

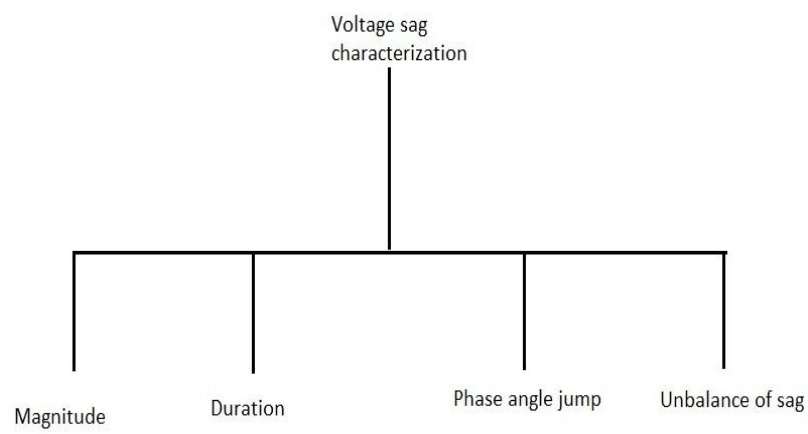

Figure 1: Characterization chart of voltage sag
Magnitude- It is defined as the voltage remained at the time of fault. For three phases, the lowest remaining voltage among all the three phases is considered.

Duration - This is the time period for which the RMS value of the voltage is below the threshold value of the voltage. Duration of sag completely depends on the fault clearing time [7] and on the basis of this; it is further classified as rectangular and non- rectangular sag.

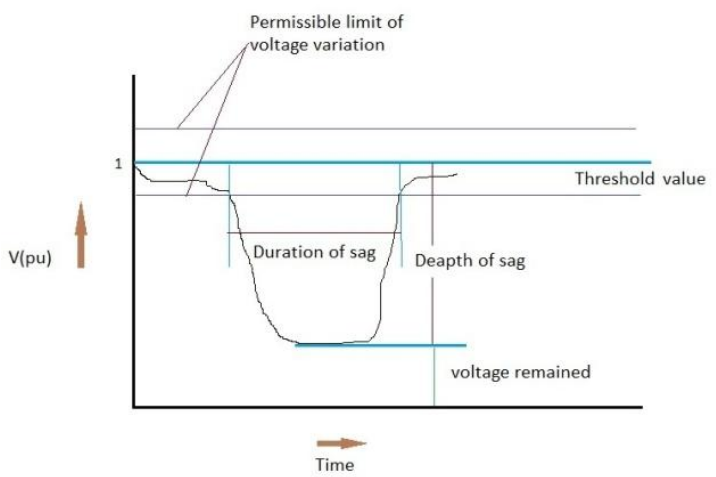

Figure 2: Duration curve

Phase angle jump- To calculate this, phase angle before the sag and phase angle after the sag is plotted in time domain as per shift in voltage zero-crossing.

Unbalance of sag- Sag due to unsymmetrical fault in all the three phases is different which affects the transformer connections.

\section{B. Causes and effect}

Voltage sag caused or say occurred by both sides that is from utility and end users and also there are natural causes which make the voltage to go down below the RMS value. From utility side by frequent switching on and off of equipments, circuit breakers, disconnections of reclosures etc.[3][8] These are characterized under single line to 


\section{International Journal of Science and Research (IJSR) \\ ISSN (Online): 2319-7064}

Index Copernicus Value (2013): 6.14 | Impact Factor (2014): 5.611

ground, two line to ground, line to line and three phase faults. From end users side due to adaptation of rectangular use of non-linear loads, using motors those which require high current etc.[9] At last but not the least natural reasons of voltage sag which are generally seen frequently are animals and trees coming in contact with the transmission lines, lightning strikes etc. Effects of voltage sag on the whole system are as follows-[11]

1. System losses increase.

2. Customer dissatisfaction due to poor quality of power being supplied to them.

3. Demand of reactive power increases.

4. Maintenance cost increases which is quite uneconomical.

\section{Area Affected by Voltage Sag}

\section{A. Importance of study of area effected}

Voltage sag performance estimation is very important so that according to it, one can plan or design the whole system.[1] To assure compatibility between supply system and the facilities, important steps followed are [10]

1. First find out the number and characteristics of voltage sag.

2. Second find out the equipment which is sensitive to voltage sags.

3. Third find out the better economic solution which helps in improving the performance that is less voltage sag on the system or good immunity of the equipment connected.

To study out effective area of voltage sag one of the important term used is area of vulnerability.

\section{B. Area of vulnerability}

Area of vulnerability is a term concerned about the minimum voltage equipment can withstand without failure of operation that is the equipment ride through capability against voltage. [4] This is also termed as equipment susceptibility limit or voltage sag immunity.

To determine the area of vulnerability the total circuit area comes under the voltage sag which makes the end user's equipment to drop below the ride through capability of voltage. Voltage sag effects can be reduced by reducing area of vulnerability that is area affected by voltage sag.

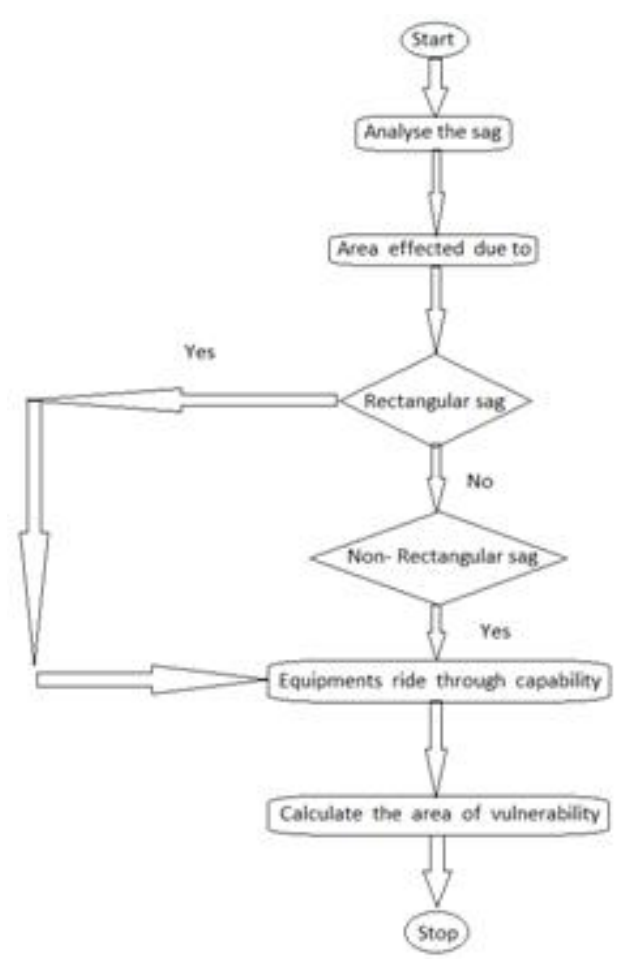

Figure 3: Flowchart to calculate effective area due to voltage sag

\section{Estimation of voltage ride-through capability of equipment}

Estimation of voltage ride-through capability of equipment is very important part in order to calculate area of vulnerability. In conventional method of estimation of voltage tolerance curve, only rectangular sag are considered. In rectangular sag, the curve has very sharp drop at the starting of the sag as well as sharp rise at the end in case of non-rectangular sag, the effect on equipment can be overestimated. In this method individual customer equipment cannot be considered which in turn results in effect of different equipment cannot be calculated out. Non-rectangular sag is generated due to induction motor starting.
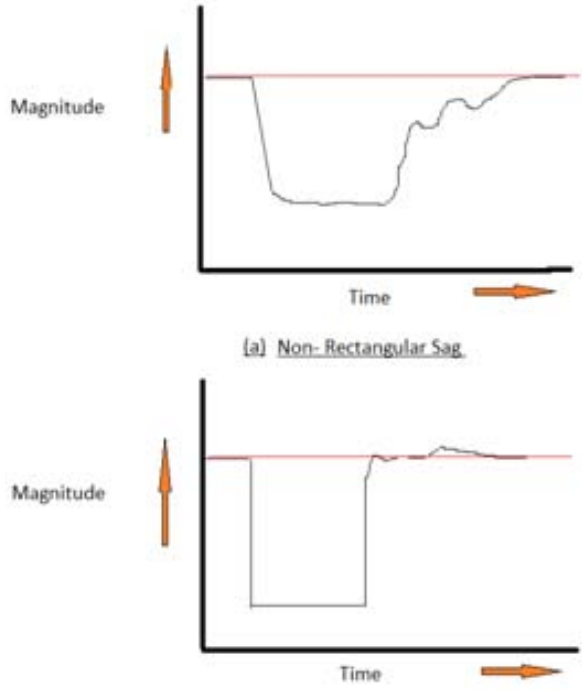

[b] Rectansular $\mathrm{Sag}$

Figure 4: Rectangular and Non-Rectangular sag 


\section{International Journal of Science and Research (IJSR) \\ ISSN (Online): 2319-7064 \\ Index Copernicus Value (2013): 6.14 | Impact Factor (2014): 5.611}

To come out of these limitations, new method is applied in which voltage profile during sag also includes values of sag voltage, average voltage, minimum voltage and duration.[5] In this method both rectangular as well as non-rectangular sag are calculated and also each equipment voltage ride-through capability can be estimated.

\section{Faults}

\section{A. Two line (or phase) to ground fault - (DLG)}

This type of fault occurs because of short circuit between lines (or phases) and the ground. For simulation of this fault, negative and zero-sequence network are connected in parallel.

\section{B. Single line (or phase) to ground fault - (SLG)}

In this short circuit takes place in between any one of the lines or phase conductors and earth due to insulation failure or due to breaking of line. In this type of fault, large phase angle jump is seen.

\section{Three phase fault - (3Ф)}

In three phase fault only positive sequence current is present while the negative and zero sequence current are absent. Positive sequence current component is equal to the phase current and also it is not affected by mutual coupling.

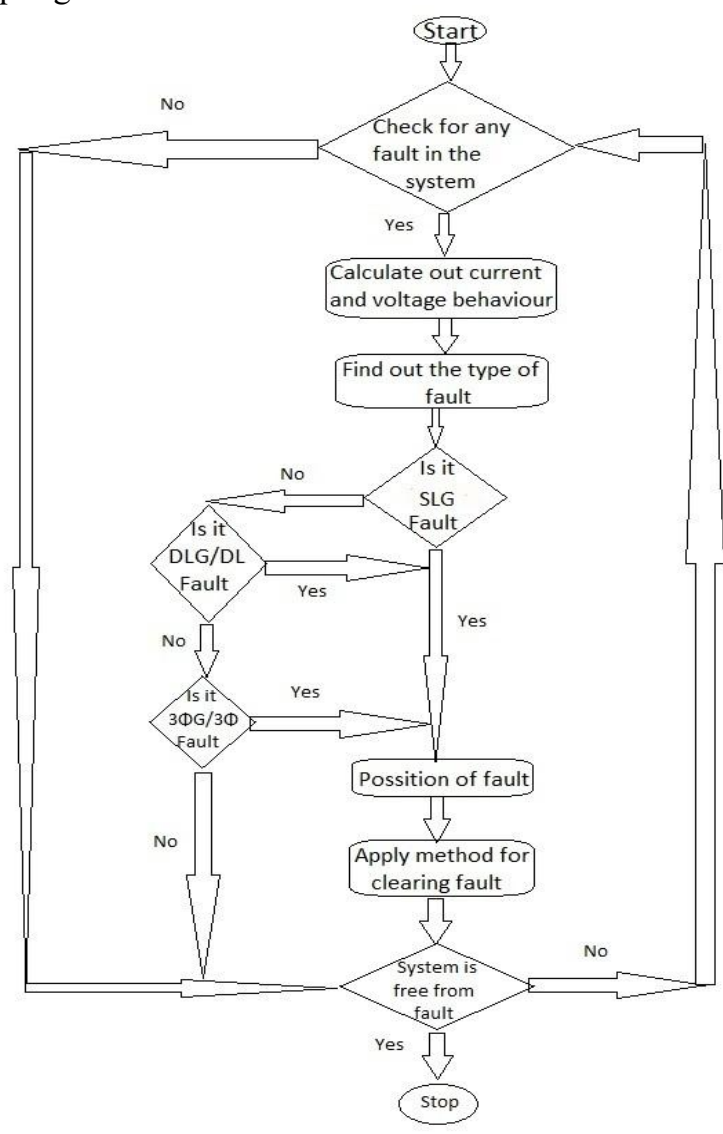

Figure 5: Flowchart for fault analysis

\section{Comparison with Simulation}

To simulate different types of fault on different types of transformer connections and study the intensity of sag, MATLAB is used. Single line diagram of the modeled system is shown in figure.

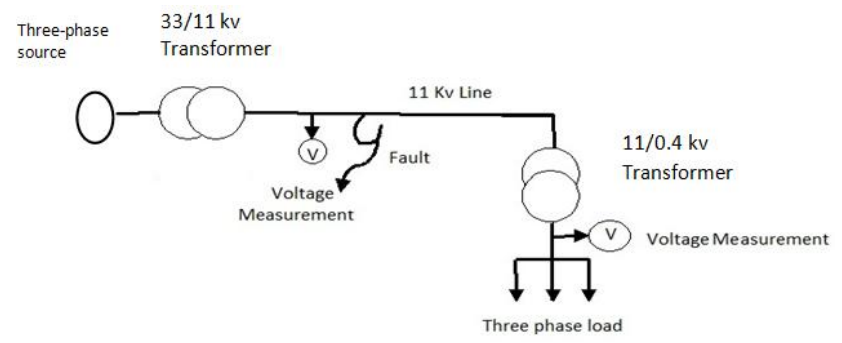

Figure 6: Single Line Diagram

Table 1: Parameters of simulation model Source $8 \mathrm{MVA}, \mathrm{X} / \mathrm{R}=10$

Transformer $200 \mathrm{KVA}, 11 / 0.4 \mathrm{Kv}$

Frequency $50 \mathrm{~Hz}$

Load $140 \mathrm{KW}, 10 \mathrm{KVAR}$

Graphs obtained from MATLAB on simulating fault are as follows.

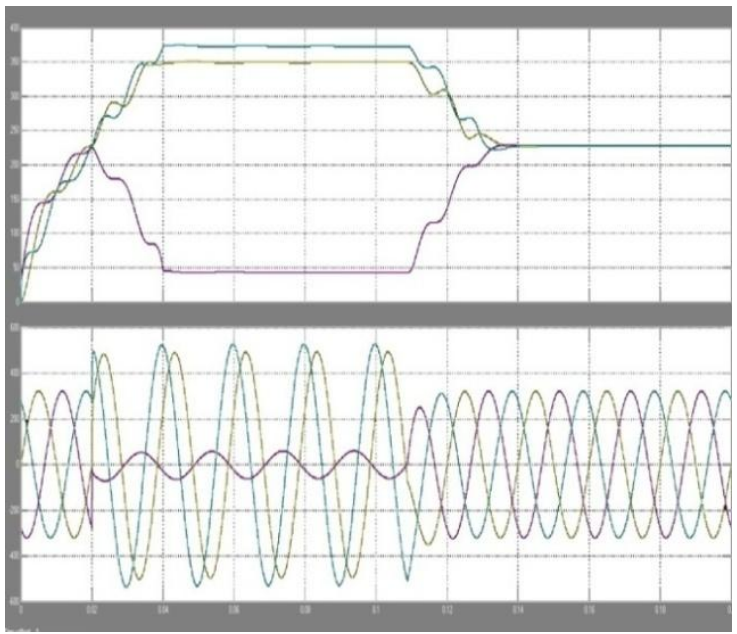

Figure 7: Single Line to Ground Fault

(a) For $\mathrm{Y}_{\mathrm{g}}-\mathrm{Y}_{\mathrm{g}}$ Transformer Connection

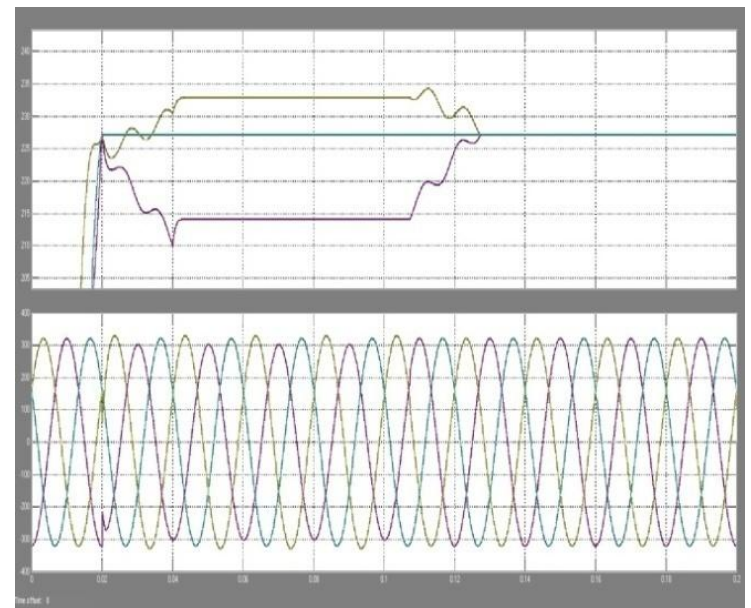

Figure 8: Single Line to Ground Fault 


\section{International Journal of Science and Research (IJSR) \\ ISSN (Online): 2319-7064}

Index Copernicus Value (2013): 6.14 | Impact Factor (2014): 5.611

(b) For $\mathrm{Y}_{\mathrm{g}}-\mathrm{D} 11$ Transformer Connection

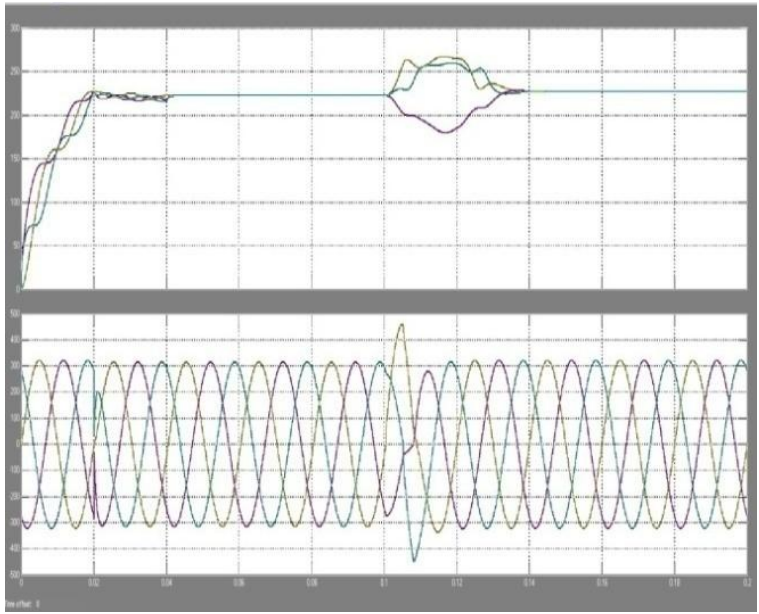

Figure 9: Three Phase Fault for $\mathrm{Y}_{\mathrm{g}}-\mathrm{Y}_{\mathrm{g}}$ Transformer Connection

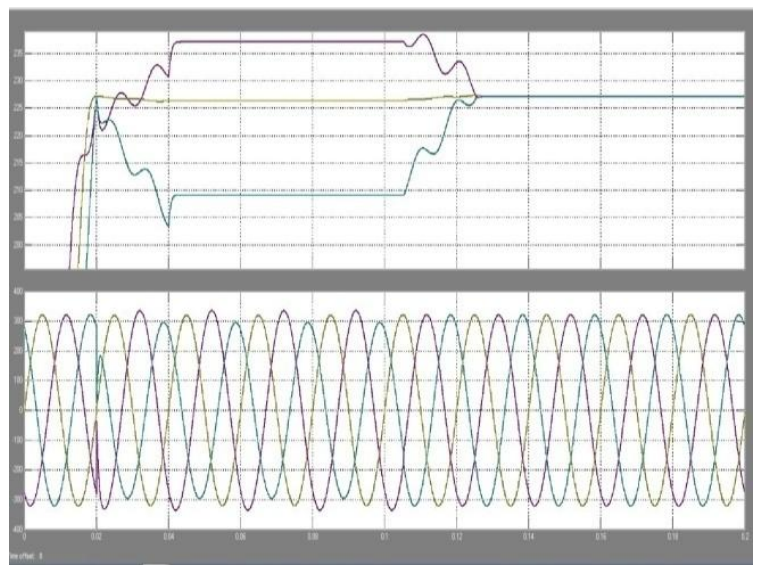

Figure 10: Double Line to Ground Fault for $Y_{g}-Y$ Transformer Connection

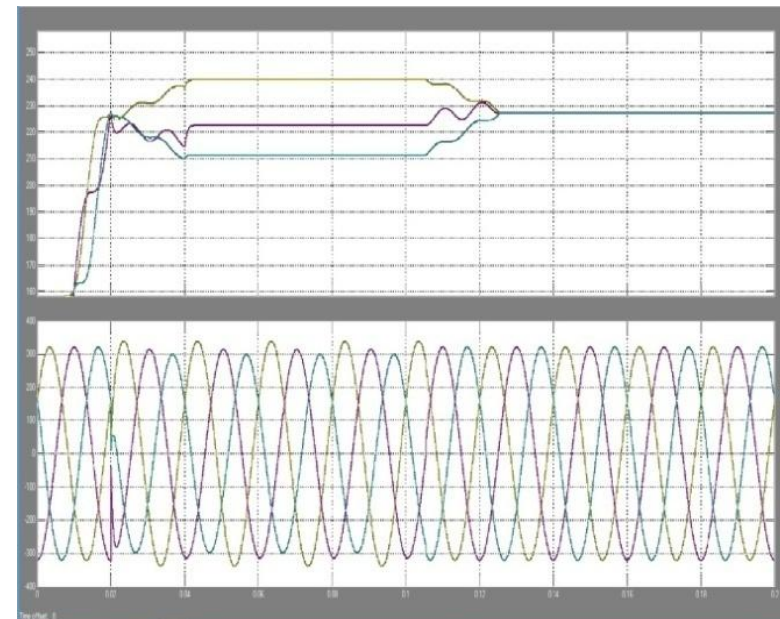

Figure 11: Double Line Fault for $\mathrm{Y}_{\mathrm{g}}$-D11 Transformer Connection

Tables giving information obtained by simulation of faults on different transformer connections are as follows.
Table 2: $\mathrm{Y}_{\mathrm{g}}-\mathrm{Y}_{\mathrm{g}}$ Transformer connection

\begin{tabular}{|l|c|c|c|}
\hline \multicolumn{1}{|c|}{ Type of fault } & $\begin{array}{c}\text { Pre-fault } \\
\text { RMS } \\
\text { Voltage }\end{array}$ & $\begin{array}{c}\text { Post-fault } \\
\text { RMS } \\
\text { Voltage }\end{array}$ & \% Sag \\
\hline $\begin{array}{l}\text { Single line to } \\
\text { ground }\end{array}$ & 220 & 34.97 & 84.10 \\
\hline $\begin{array}{l}\text { Three phase to } \\
\text { ground }\end{array}$ & 220 & 172.48 & 21.60 \\
\hline Three phase & 220 & 213.24 & 3.07 \\
\hline $\begin{array}{l}\text { Double line to } \\
\text { ground }\end{array}$ & 220 & 167.32 & 23.94 \\
\hline Double line & 220 & 196.16 & 10.83 \\
\hline
\end{tabular}

Table 3: $\mathrm{Y}_{\mathrm{g}}$-Y Transformer connection

\begin{tabular}{|c|c|c|c|}
\hline Type offault & $\begin{array}{c}\text { Pre-fault } \\
\text { RMS } \\
\text { Voltage }\end{array}$ & $\begin{array}{c}\text { Post-fault } \\
\text { RMS } \\
\text { Voltage }\end{array}$ & $\%$ Sag \\
\hline $\begin{array}{c}\text { Single line to } \\
\text { ground }\end{array}$ & 220 & 216.52 & 1.58 \\
\hline $\begin{array}{c}\text { Three phase to } \\
\text { ground }\end{array}$ & 220 & 213.32 & 3.03 \\
\hline Three phase & 220 & 213.24 & 3.07 \\
\hline $\begin{array}{c}\text { Double line to } \\
\text { ground }\end{array}$ & 220 & 196.35 & 10.75 \\
\hline Double line & 220 & 196.16 & 10.83 \\
\hline
\end{tabular}

Table 4: $\mathrm{Y}_{\mathrm{g}}$-D11 Transformer connection

\begin{tabular}{|c|c|c|c|}
\hline Type of fault & $\begin{array}{c}\text { Pre-fault } \\
\text { RMS } \\
\text { Voltage }\end{array}$ & $\begin{array}{c}\text { Post-fault } \\
\text { RMS } \\
\text { Voltage }\end{array}$ & \% Sag \\
\hline $\begin{array}{c}\text { Single line to } \\
\text { ground }\end{array}$ & 220 & 202.90 & 7.77 \\
\hline $\begin{array}{c}\text { Three phase to } \\
\text { ground }\end{array}$ & 220 & 214.79 & 2.36 \\
\hline Three phase & 220 & 214.04 & 2.70 \\
\hline $\begin{array}{c}\text { Double line to } \\
\text { ground }\end{array}$ & 220 & 204.90 & 6.86 \\
\hline Double line & 220 & 202.88 & 7.78 \\
\hline
\end{tabular}

\section{Conclusion}

From table it is clear that single line to ground fault is quite observable when transformer is $\mathrm{Y}_{\mathrm{g}}-\mathrm{Y}_{\mathrm{g}}$ connected while intensity is low on $\mathrm{Y}_{\mathrm{g}}-\mathrm{Y}$ transformer connection. On comparing transformer connections, $\mathrm{Y}_{\mathrm{g}}-\mathrm{Y}$ two line faults are more observable than transformer $Y_{g}-\Delta 11$ connection. Noticeable three phase fault is obtained when transformer is $\mathrm{Y}_{\mathrm{g}}-\mathrm{Y}_{\mathrm{g}}$ connected.

Although voltage sag can be simulated in other software but here MATLAB is used. With time to time advancement in the software feature, we can get exact and precise value of the result obtained.

Here simulation on different types of transformer connection effects on different type of fault is done, in future it can give even better results with upgraded MATLAB tools.

\section{References}

[1] (2009) IEEE Recommended Practice for Monitoring Electric Power Quality. IEEE Std. 1159-2009.

[2] P.Heine and M. Lehtonen, (2003) Voltage Sag Distributions Caused by Power Systems Faults. IEEE 
Transactions on Power Systems, 18, 1367-1373. http://dx.doi.org/10.1109/TPWRS.2003.818606

[3] R. Naidoo and P.Pillay (2007) A New Method of Voltage Sag and Swell Detection. IEEE Transactions on Power Delivery, 22, 1056-1063. http://dx.doi.org/10.1109/TPWRD.2007.893185

[4] E.E. Juarez and A. Hernandez (2006) An Analytical Approach for Stochastic Assessment OG Balanced and Unbalanced Voltage Sags in Large Systems. IEEE Transactions on Power Delivery, 21, 14931500.http://dx.doi.org/10.1109/TPWRD.2005.860266

[5] D.-J. Won, S.-J. Ahn and Y.Chung, (2003) A New Definition of Voltage Sag Duration Considering the Voltage Tolerance Curve. IEEE Bologna Power Tech Conference, Bologna, 4, 23-26 June 2003.

[6] L.D. Zhang and M.H.J.Bollen, (2000) Characteristic of Voltage Dips (Sags) in Power Systems. IEEE Transactions on Power Delivery, 25, 827-832.

[7] Larry Conard, Kevin Little and Cliff Grigg (1991) Predicting And Preventing Problems Associated With Remote Fault-Clearing Voltage Dips. IEEE Transactions on Industry Applications, 27.

[8] (1998) IEEE Recommended Practice for Evaluating Electrical Power System Compatibility With Electronic Process Equipment. IEEE Std.1346-1998.

[9] F.R.Zaro, M.A.Abibo, S.Ameenuddin and I.M.Elamin (2012) Characterization of Short-Duration Voltage Events. IEEE International Conference on Power and Energy (PECon).

[10] R.C.Duggan, M.F.McGranaghan, and H.W.Beaty, Electrical power systems quality vol.2: McGraw-Hill New York, 1996.

[11] S.Khokhar, A.A. Mohd Zin, A.S.Mokhtar, NAM Ismail (2014) MATLAB/Simulink Based Modeling and Simulation of Power Quality Disturbances. IEEE

\section{Author Profiles}

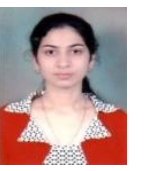

Parijat Deb is M.Tech Scholar in Power System at Gyan Ganga College of Technology, Jabalpur (M.P.)

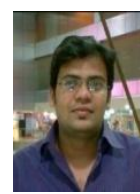

Amit Gupta is Asst. Professor in Electrical and Electronics Department at Gyan Ganga College of Technology, Jabalpur (M.P) 